\title{
Cumulative effect of potassium and gibberellic acid on growth, biochemical attributes and productivity of F1 hybrid cucumber
}

\author{
Priyanka Pal ${ }^{1}$, Kuldeep Yadav ${ }^{1}$, Krishan Kumar ${ }^{2}$, Narender Singh ${ }^{1 *}$ \\ ${ }^{1}$ Department of Botany, Kurukshetra University, Kurukshetra, Haryana, India \\ ${ }^{2}$ Centre of Excellence for Vegetables Indo-Israel, Gharaunda (Karnal), Haryana, India \\ •Corresponding author, E-mail: nsheorankukbot11@gmail.com,nsheorankuk@yahoo.com
}

\begin{abstract}
Cucumis sativus L. is an important fruit vegetable with great economic potential. A study was carried out to evaluate the potential of exogenously applied potassium nitrate $\left[1.0\left(\mathrm{~K}_{1}\right), 2.5\left(\mathrm{~K}_{2}\right), 5\left(\mathrm{~K}_{3}\right) \mathrm{g} \mathrm{L}^{-1}\right]$ and gibberellic acid $\left[0.005\left(\mathrm{G}_{1}\right), 0.01\left(\mathrm{G}_{2}\right), 0.015\left(\mathrm{G}_{3}\right) \mathrm{g} \mathrm{L} \mathrm{L}^{-1}\right]$ in combination on growth, development and yield of the F1 hybrid cucumber cv. 'KUK-9' under protected cultivation. Growth and physiological parameters like vine length, fresh weight, dry weight, number of branches, number of leaves, growth rate, biomass duration, chlorophyll and mineral content were observed after 70 days. Overall results suggest that all the combination treatments showed beneficial effects over the control, but foliar application of $\mathrm{G}_{2} \mathrm{~K}_{2}$ had maximum effect on growth and development of plants. Total yield and fruit quality were also significantly higher in $\mathrm{G}_{2} \mathrm{~K}_{2}$ treatment than in other treatments. Foliar application of potassium and gibberellic acid may be effective to maximize cucumber growth, physiological status and yield parameters.
\end{abstract}

Key words: Cucumis sativus, gibberellic acid, growth, potassium, yield.

Abbreviations: AGR, absolute growth rate; $\mathrm{BMD}$, biomass duration; $\mathrm{GA}_{3}$, gibberellic acid; $\mathrm{K}$, potassium; RGR, relative growth rate.

\section{Introduction}

Cucumis sativus L. (Cucurbitaceae) is an important fruit vegetable with great economic potential. It is an excellent source of minerals and vitamins for the human body with a very low caloric value (Wang et al. 1997).

Endogenous plant growth regulators are known to control vital physiological and biochemical processes of plants (Sharma et al. 2013). Exogenous application of plant growth regulators is a well-recognized strategy to enhance yield, improve quality and to protect plants from adverse effects of the environment (Dashora, Jain 1994). Foliar spray is an emerging method for crop fertilization and is usually preferred over root fertilization because of its higher efficiency and lower cost (Nasiri et al. 2010). Generally, a balanced supply of nutrients in optimal concentration is essential for optimum yield and fruit quality in different vegetables (Akhter et al. 2010).

Potassium $(\mathrm{K})$ is one of the essential plant mineral nutrients and its availability is associated with photosynthesis, enzyme activation, cell turgor maintenance and ion homeostasis (Fawzy et al. 2007). Gibberellic acid $\left(\mathrm{GA}_{3}\right)$ is a potent plant growth regulator, reported to stimulate vegetative growth, flowering and fruiting in many agricultural and horticultural crops (Paroussi et al. 2002; Elsese et al. 2005).
Vegetables are a good source of minerals, vitamins and dietary fibre and contribute to preventing micronutrient deficiencies and promoting healthy bowel function (Hollingswortn 1981). Therefore, efforts are being made to use methods of applying nutrients for increasing yield. Despite various studies carried out on the soil and plant nutrition, only a few studies have been conducted on parthenocarpic vegetables. Keeping the above in mind, the aim of the present study was to investigate the effects of foliar application of $\mathrm{K}$ and $\mathrm{GA}_{3}$ on growth and yield of $\mathrm{F} 1$ hybrid cucumber cv. 'KUK-9'.

\section{Materials and methods}

\section{Site and treatments}

The experiment was conducted in net house at the Centre of Excellence for Vegetables Indo-Israel, Gharaunda (Karnal) at N 29³2', E 76 59' from September to December 2015. Normal temperatures during this period are 17 to $27{ }^{\circ} \mathrm{C}$ (night) and 32 to $34^{\circ} \mathrm{C}$ (day). The $\mathrm{F} 1$ hybrid parthenocarpic cucumber cv. 'KUK-9' obtained from the Indo-Israel Centre was used. The physical and chemical properties of the soil up to $30 \mathrm{~cm}$ depth at the experimental site were $82.20 \%$ sand, $11.19 \%$ clay, $6.11 \%$ silt, $\mathrm{pH} 7.7,146.50 \mathrm{~kg} \mathrm{ha}^{-1}$ of $\mathrm{K}$, $15.23 \mathrm{~kg} \mathrm{ha}^{-1}$ of $\mathrm{P}$ and $12.3 \%$ moisture.

Treatments included foliar application of four 
Table 1. Effect of foliar spray of potassium and gibberellic acid on vine and root length, number of branch and leaves of parthenocarpic

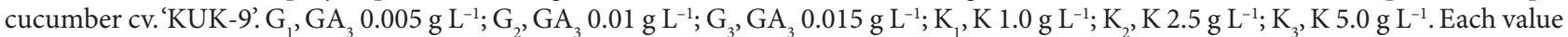
is a mean of five replicates, values in column followed by same letter are not significantly different

$\begin{array}{lcccc}\text { Treatment } & \text { Vine length }(\mathbf{c m}) & \text { Root length }(\mathbf{c m}) & \text { Number of branches } & \text { Number of leaves } \\ \text { Control } & 162.0 \mathrm{c} & 16.0 \mathrm{c} & 23.3 \mathrm{c} & 142.0 \mathrm{c} \\ \mathrm{G}_{1} \mathrm{~K}_{1} & 281.6 \mathrm{~b} & 21.0 \mathrm{~b} & 26.6 \mathrm{a} & 166.0 \mathrm{ab} \\ \mathrm{G}_{2} \mathrm{~K}_{2} & 293.6 \mathrm{a} & 25.0 \mathrm{a} & 27.0 \mathrm{a} & 169.0 \mathrm{a} \\ \mathrm{G}_{3} \mathrm{~K}_{3} & 277.0 \mathrm{bc} & 18.1 \mathrm{bc} & 24.3 \mathrm{ab} & 164.0 \mathrm{~b} \\ \mathrm{LSD}(P \leq 0.05) & 7.931 & 3.99 & 2.97 & 67.99 \\ \text { ANOVA }\left(\mathrm{F}_{3,8}\right) & 640.15^{\star *} & 14.03^{\star *} & 3.82^{* *} & 4.89^{* *}\end{array}$

concentrations of gibberellic acid $\left[0\left(\mathrm{G}_{0}\right), 0.005\left(\mathrm{G}_{1}\right), 0.01\right.$ $\left.\left(G_{2}\right), 0.015\left(G_{3}\right) g^{-1}\right]$ together with four concentrations of potassium [0 $\left(\mathrm{K}_{0}\right), 1.0\left(\mathrm{~K}_{1}\right), 2.5\left(\mathrm{~K}_{2}\right)$ and $\left.5.0\left(\mathrm{~K}_{3}\right) \mathrm{g} \mathrm{L}^{-1}\right]$ in a form of potassium nitrate. Four different treatment combinations were used in the experiment: $\mathrm{G}_{0} \mathrm{~K}_{0}$ (control), $\mathrm{G}_{1} \mathrm{~K}_{1}, \mathrm{G}_{2} \mathrm{~K}_{2}$ and $\mathrm{G}_{3} \mathrm{~K}_{3}$. $\mathrm{K}$ and $\mathrm{GA3}$ were prepared with distilled water and applied to foliage with a power spray/ knap sack spray pump until complete wetting. Treatments were applied in the morning with a single day interval. All the other agriculture practices i.e., irrigation, hoeing and weeding were carried out throughout the growing season. Data on vine length, number of leaves, number of branches, root length, fresh and dry weight, absolute growth rate (AGR), relative growth rate (RGR), biomass duration (BMD), leaf chlorophyll concentration, carotenoid concentration, sodium, magnesium and calcium concentration and fruit yield (fruit set \%, fresh and dry weight) were recorded at final harvest (70 days).

\section{Growth analysis}

Vine length and root length were measured from the coteledonary node to the growing tip. Total numbers of branches and leaves originating from the main stem of each plant were counted. Dry weight per plant was determined after plants were removed from soil. The plants were dried in a forced air oven at $70{ }^{\circ} \mathrm{C}$ until a constant weight was obtained. AGR (dry matter production per unit time) was calculated using the formula of Radford (1967). RGR is the rate of increase in dry weight per unit dry weight already accumulated and calculated using the formula of Blackman
(1919). BMD, the magnitude and duration of a crop time, was calculated using the formula of Sestak et al. (1971).

\section{Biochemical analysis}

Among biochemical parameters, leaf chlorophyll concentration was measured as described by Arnon (1949). Leaf carotenoid concentration was measured using the method of Lichtenthaler and Welburn (1983). Leaves were dried to a constant weight at $70{ }^{\circ} \mathrm{C}$ and ground to form a powder such that it could pass through a $1.0 \mathrm{~mm}$ sieve. Well-mixed, dried plant samples were weighed $(0.5 \mathrm{~g})$ and dissolved in $5 \mathrm{~mL}$ of $2 \mathrm{~N} \mathrm{HCl}$ for determination of $\mathrm{Mg}$ and $\mathrm{Ca}$. Concentrations were determined by atomic absorption spectrophotometer (model 2380, Perkin-Elmer, US) using the method of AOAC (1990). Sodium content was assayed using a flame spectrometer.

\section{Statistical analysis}

All experiments were conducted with a minimum of five replicates per treatment and were repeated three times. The data were analyzed statistically using one-way analysis of variance (ANOVA) and the differences contrasted using a Duncan's multiple range test at $P \leq 0.05$. All statistical analyses were performed using the SPSS (version 11.5) program.

\section{Results}

Exogenous application of $\mathrm{K}$ and $\mathrm{GA}_{3}$ on parthenocarpic cucumber increased all measured growth parameters, like

Table 2. Effect of foliar spray of potassium and gibberellic acid on fresh and dry weight of stem and root of parthenocarpic cucumber cv. 'KUK-9'. $\mathrm{G}_{1}, \mathrm{GA}_{3} 0.005 \mathrm{~g} \mathrm{~L}^{-1} ; \mathrm{G}_{2}, \mathrm{GA}_{3} 0.01 \mathrm{~g} \mathrm{~L}^{-1} ; \mathrm{G}_{3}, \mathrm{GA}_{3} 0.015 \mathrm{~g} \mathrm{~L}^{-1} ; \mathrm{K}_{1}, \mathrm{~K} 1.0 \mathrm{~g} \mathrm{~L}^{-1} ; \mathrm{K}_{2}, \mathrm{~K}^{2} .5 \mathrm{~g} \mathrm{~L}^{-1} ; \mathrm{K}_{3}, \mathrm{~K}$. $0 \mathrm{~g} \mathrm{~L}^{-1}$. Each value is a mean of five replicates, values in column followed by same letter are not significantly different

$\begin{array}{lcccc}\text { Treatment } & \begin{array}{c}\text { Fresh weight of stem } \\ \text { (g per plant) }\end{array} & \begin{array}{c}\text { Fresh weight of roots } \\ \text { (g per plant) }\end{array} & \begin{array}{c}\text { Dry weight of stem } \\ \text { (g per plant) }\end{array} & \begin{array}{c}\text { Dry weight of roots } \\ \text { (g per plant) }\end{array} \\ \text { Control } & 434.0 \mathrm{~d} & 9.5 \mathrm{c} & 59.0 \mathrm{~d} & 1.23 \mathrm{c} \\ \mathrm{G}_{1} \mathrm{~K}_{1} & 496.0 \mathrm{~b} & 10.3 \mathrm{~b} & 71.3 \mathrm{~b} & 1.16 \mathrm{~b} \\ \mathrm{G}_{2} \mathrm{~K}_{2} & 598.0 \mathrm{a} & 12.4 \mathrm{a} & 116.0 \mathrm{a} & 1.89 \mathrm{a} \\ \mathrm{G}_{3} \mathrm{~K}_{3} & 482.0 \mathrm{c} & 10.1 \mathrm{~b} & 68.0 \mathrm{c} & 1.04 \mathrm{c} \\ \mathrm{LSD}(P \leq 0.05) & 7.128 & 0.243 & 3.305 & 0.0318 \\ \mathrm{ANOVA}\left(\mathrm{F}_{3,8}\right) & 995.49^{* *} & 275.11^{* *} & 631.81^{* *} & 1.79^{* *}\end{array}$


Table 3. Effect of foliar spray of potassium and gibberellic acid on growth parameters of parthenocarpic cucumber $\mathrm{cv}^{\text {' }} \mathrm{KUK}-\mathrm{g}^{\prime}$. $\mathrm{G}_{1}, \mathrm{GA}_{3}$

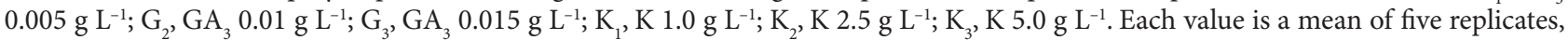
values in column followed by same letter are not significantly different

$\begin{array}{lccc}\text { Treatment } & \begin{array}{c}\text { Absolute growth rate } \\ \text { (g per day per plant) }\end{array} & \begin{array}{c}\text { Relative growth rate } \\ \left(\mathbf{g ~ g ~}^{-1} \text { per day per plant }\right)\end{array} & \begin{array}{c}\text { Biomass duration } \\ (\mathbf{g} \text { days })\end{array} \\ \text { Control } & 0.120 \mathrm{c} & 0.031 \mathrm{~cd} & 833.4 \mathrm{~d} \\ \mathrm{G}_{1} \mathrm{~K}_{1} & 0.340 \mathrm{~b} & 0.035 \mathrm{~b} & 924.5 \mathrm{~b} \\ \mathrm{G}_{2} \mathrm{~K}_{2} & 0.390 \mathrm{a} & 0.037 \mathrm{a} & 936.2 \mathrm{a} \\ \mathrm{G}_{3} \mathrm{~K}_{3} & 0.316 \mathrm{~b} & 0.033 \mathrm{bc} & 902.7 \mathrm{c} \\ \mathrm{LSD}(P \leq 0.05) & 0.0331 & 0.0042 & 0.215 \\ \mathrm{ANOVA}\left(\mathrm{F}_{3,8}\right) & 136.541^{* *} & 3.244^{* *} & 4.763^{* *}\end{array}$

vine length, branch number, number of leaves, and both fresh and dry weight of roots and shoots per plant (Table 1 and 2). A considerable increase in these parameters was

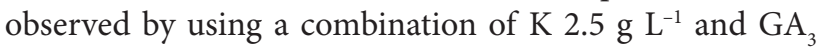
$0.010 \mathrm{~g} \mathrm{~L}^{-1}$. The control treatment $\left(\mathrm{G}_{0} \mathrm{~K}_{0}\right)$ showed lowest value for all parameters measured.

Different combinations of $\mathrm{K}$ and $\mathrm{GA}_{3}$ were also found to be more effective in promoting AGR and RGR of cucumber plants (Table 3 ). The highest AGR and RGR was recorded in treatment $G_{2} K_{2}$ followed by $G_{1} K_{1}$ and $G_{3} K_{3}$. Biomass duration (BMD) was significantly higher in the $\mathrm{K}$ $2.5 \mathrm{~g} \mathrm{~L}^{-1}$ and $\mathrm{GA}_{3} 0.010 \mathrm{~g} \mathrm{~L}^{-1}$ treatment over control. The combination of $\mathrm{K}$ and $\mathrm{GA}_{3}$ also increased leaf chlorophyll $a, b$ and carotenoid concentration of cucumber plants over control (Table 4).

The highest concentration of calcium occurred in plants in the $G_{2} K_{2}$ treatment, while the combination $G_{1} K_{1}$ showed maximum magnesium and sodium concentration (Table 4). All treatment combinations resulted in higher $\mathrm{Ca}$ concentration in comparison to that in the control (Table 4). $\mathrm{K}$ in high concentration acted as a strong competitor affecting $\mathrm{Mg}$ uptake, as the foliar spray with $\mathrm{G}_{3} \mathrm{~K}_{3}$ resulted in minimum $\mathrm{Na}$ and $\mathrm{Mg}$ concentrations, that were slightly above the control level.

Exogenously applied $\mathrm{GA}_{3}$ with $\mathrm{K}$ not only enhanced growth and physiological parameters of cucumber but also promoted fruit yield and quality (Table 5). The lowest yield was obtained in the control $\left(\mathrm{G}_{0} \mathrm{~K}_{0}\right)$. The highest relative fruit set, fruit fresh and dry weight was obtained with the combination $\mathrm{G}_{2} \mathrm{~K}_{2}$ followed by $\mathrm{G}_{1} \mathrm{~K}_{1}$.

\section{Discussion}

The results revealed that the exogenous application of different combinations of $\mathrm{K}$ and $\mathrm{GA}_{3}$ had variable effect on different growth and morphological parameters of parthenocarpic cucumber. The observed effect can be attributed to increased cell division and cell elongation induced by the foliar spray of GA3 and K (Shah et al. 2006). The results are in agreement with earlier findings of Karakurt et al. (2009), Roy and Nasiruddin (2011) and Kumar et al. (2014) in different crops. Mazumdar (2013) also noticed an increase in total plant weight using foliar application of $\mathrm{K}$ and GA3 in cabbage. Plant growth regulators promote DNA, RNA and protein synthesis resulting in increased biomass in different parts of the plant. They also regulate nutrient transport, inducing stem elongation, leaf area expansion and flowering in plants (Khan, Samiullah 2003).

An adequate combination of $\mathrm{GA}_{3}$ and $\mathrm{K}$ foliar spray can exert large effect on the fundamental processes of plant growth and development, leading to higher BMD. $\mathrm{GA}_{3}$ occupies a prominent position in mediating a variety of plant physiological processes, including seed germination, photosynthesis, translocation of food material, and synthesis of mRNA coding for hydrolytic enzymes (Tiwari et al. 2011; Khan et al. 2012; Qudassi et al. 2014).

Vanbel (1990) found that an adequate supply of K plays a key function in chlorophyll formation. Tuna et al. (2010)

Table 4. Effect of foliar spray of potassium and gibberellic acid on chlorophyll, carotenoid and mineral concentration of parthenocarpic

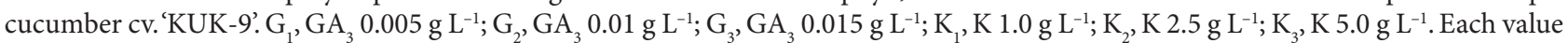
is a mean of five replicates, values in column followed by same letter are not significantly different

\begin{tabular}{|c|c|c|c|c|c|c|}
\hline Treatment & $\begin{array}{c}\text { Chlorophyll } a \\
\left(\mathrm{mg} \mathrm{g}^{-1} \mathrm{FW}\right)\end{array}$ & $\begin{array}{c}\text { Chlorophyll } b \\
\left(\mathrm{mg} \mathrm{g}^{-1} \mathrm{FW}\right)\end{array}$ & $\begin{array}{l}\text { Carotenoids } \\
(\mathrm{mg} \text { g-l FW) }\end{array}$ & Calcium (\%) & Magnesium (\%) & Sodium (\%) \\
\hline Control & $1.16 \mathrm{~d}$ & $0.72 \mathrm{~d}$ & $0.51 d$ & $1.24 \mathrm{~d}$ & $0.30 \mathrm{~b}$ & $1.23 c$ \\
\hline $\mathrm{G}_{1} \mathrm{~K}_{1}$ & $1.66 \mathrm{~b}$ & $0.94 \mathrm{~b}$ & $0.80 \mathrm{~b}$ & $1.55 \mathrm{~b}$ & $0.33 \mathrm{a}$ & $0.36 \mathrm{a}$ \\
\hline $\mathrm{G}_{2} \mathrm{~K}_{2}$ & $2.19 a$ & $1.73 a$ & $0.98 \mathrm{a}$ & $2.92 \mathrm{a}$ & $0.34 \mathrm{a}$ & $0.33 b$ \\
\hline $\mathrm{G}_{3} \mathrm{~K}_{3}$ & $1.45 \mathrm{c}$ & $0.83 c$ & $0.67 \mathrm{c}$ & $1.44 \mathrm{c}$ & $0.31 b$ & $0.29 c$ \\
\hline $\operatorname{LSD}(P \leq 0.05)$ & 0.033 & 0.0348 & 0.113 & 0.038 & 0.203 & 0.0318 \\
\hline ANOVA $\left(\mathrm{F}_{3,8}\right)$ & $1.846^{* *}$ & $1.838^{* *}$ & $32.48^{* *}$ & $9.605^{\star *}$ & $8.095^{\star *}$ & $1.79^{\star *}$ \\
\hline
\end{tabular}


Table 5. Effect of foliar spray of potassium and gibberellic acid on fruit yield attributes of parthenocarpic cucumber $\mathrm{cv}^{\text {' }} \mathrm{KUK}-\mathrm{g}^{\prime}$. $\mathrm{G}_{1}, \mathrm{GA}_{3}$

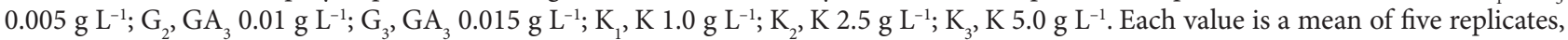
values in column followed by same letter are not significantly different

$\begin{array}{lccc}\text { Treatment } & \text { Fruit set (\%) } & \text { Fresh weight of fruit }(\mathbf{g}) & \text { Dry weight of fruit }(\mathbf{g}) \\ \text { Control } & 68.0 \mathrm{~d} & 114.0 \mathrm{~d} & 19.1 \mathrm{c} \\ \mathrm{G}_{1} \mathrm{~K}_{1} & 85.1 \mathrm{~b} & 174.2 \mathrm{~b} & 30.2 \mathrm{~b} \\ \mathrm{G}_{2} \mathrm{~K}_{2} & 91.2 \mathrm{a} & 209.3 \mathrm{a} & 43.1 \mathrm{a} \\ \mathrm{G}_{3} \mathrm{~K}_{3} & 80.0 \mathrm{c} & 167.1 \mathrm{c} & 29.0 \mathrm{c} \\ \mathrm{LSD}(P \leq 0.05) & 0.175 & 0.96 & 0.205 \\ \text { ANOVA }\left(\mathrm{F}_{3,8}\right) & 3.32^{* *} & 1.781 & 2.501^{* *}\end{array}$

also observed an increase in chlorophyll and carotenoid content in salinity stressed maize plants after foliar application of $\mathrm{GA}_{3}$. In contrast, Anderson and Robertson (1960) noticed alteration in carotenoid formation leading to photodestruction of chlorophyll by application of various chemicals to plant.

$\mathrm{K}$ at a high concentration acts as a strong competitor affecting Mg uptake. Koukoulakis et al. (1988) observed an antagonism effect on $\mathrm{Mg}$ of tomato leaves with increased levels of $\mathrm{K} . \mathrm{GA}_{3}$ increases the $\mathrm{Ca}^{2+}$ activity affiliated with endoplasmic reticulum and activates $\mathrm{Ca}^{2+}$ flux across the plasma membrane (Bush et al. 1993). Antagonistic correlations between potassium and sodium were also reported by Hey, Kramer (1993) and Song, Fujiyama (1996).

Talon et al. (1992), Deckers (2002) and Dorcey et al. (2009) also reported that foliar application of plant growth regulating substances, particularly $\mathrm{GA}_{3}$, have positive effect on yield quality and quantity. It may be due to the fact that during flowering and fruit setting stages, there is a critical demand for physiological activation to perform biological reactions in plants, which require a high amount of $\mathrm{K}$ and other nutrients (Ding et al. 2006).

In conclusion, foliar application of $\mathrm{K}$ and $\mathrm{GA}_{3}$ in the appropriate combination at optimal concentration, particularly $\mathrm{G}_{2} \mathrm{~K}_{2}$, may be an effective strategy to maximize the growth and development of parthenocarpic cucumber. This combination can be tested further under field conditions and can be recommended to farmers after proper confirmation.

\section{Acknowledgements}

The authors are grateful to Kurukshetra University, Kurukshetra, India for providing laboratory and other infrastructural facilities. Thanks are also owed to Dr. Satyender Yadav and Dr. Dharam Singh, Centre of Excellence for Vegetable Indo-Israel, Karnal, India for assistance during the research work.

\section{References}

Akhtar M.E., Khan M.Z., Rashis M.T., Ahsan Z., Ahmad S. 2010. Effect of potash application on yield and quality of tomato (Lycopersicon esculentum Mill.). Pak. J. Bot. 42: 1695-1702.

Anderson S.J., Jarrell W.M., Franco-Vizcaino, E. 1998. Effects of concentration and treatment duration upon dwarf pea response to gibberellic acid root treatments in solution culture. Plant Soil 112: 279-287.

AOAC (Association of Official Analytical Chemists). 1990. Official Methods of Analysis. $15^{\text {th }}$ Ed. Washington DC: Association of Official Analytical Chemists.

Arnon D.L. 1949. Copper enzymes in isolated chloroplast, polyphenoloxidase in Beta vulgaris. Plant Physiol. 24: 1-15.

Blackman V.H. 1919. The compound interest law and plant growth. Ann. Bot. 33: 353-360.

Bush D.S., Biswas A.K., Jones R.L. 1993. Hormonal regulation of $\mathrm{Ca}^{2+}$ transport in the endomembrane system of the barley aleurone. Planta 189: 507-515.

Dashora L.D., Jain P.M. 1994. Effect of growth regulators and phosphorus levels on growth and yield of soybean. Madras Agric. J. 81: 235-237.

Deckers T., Schoofs H. 2002. Improvement of fruit set on young pear trees cultivar with gibberellins. Acta Hortic. 596: 735-743.

Ding Y., Luo W., Xu G. 2006. Characterization of magnesium nutrition and interaction of magnesium and potassium in rice. Ann. Appl. Biol. 149: 111-123.

Dutta B., Banik A.K. 2006. Influence of plant growth regulator on yield, phsio-chemical qualities and leaf mineral composition of sardar guava grown in red and laterite tract of West Bangal. Hortic. J. 19: 356-357.

El-Sese A.M.A. 2005. Effect of gibberellic acid (GAs) on yield and fruit characteristics of Balady mandarin. Assiut. J. Agric. Sci. 36: 23-35.

Fawzy Z.F., El-Nemr M.A., Saleh S.A. 2007. Influence of levels and methods of potassium fertilizer application on growth and yield of eggplant. J. Appl. Sci. Res. 3: 42-49.

Hey T., Kramer G.R. 1993. Cellular response of two rapid cycling Brassica species, B. napus and B. carinata to seawater salinity. Physiol. Plant. 87: 47-60.

Hollingswortn D.F. 1981. The place of potatoes and other vegetables in the diet. In Spedding C.R.W. (ed) Vegetable Productivity. Macmillan London, pp. 6-13.

Karakurt Y., Unlu H., Padem H. 2009. The influence of foliar and soil fertilization of humic acid on yield and quality of pepper. Acta Agric. Scand. 59: 233-237.

Kazemi M. 2014. Effect of gibberellic acid and potassium nitrate spray on vegetative growth and reproductive characteristics of tomato. J. Biol. Environ. Sci. 8: 1-9.

Khan N.A., Samiullah. 2003. Comparative effect of modes of gibberellic acid application on photosynthesis rate, biomass distribution and productivity of rape seed mustard. Physiol. Mol. Biol. Plants 9: 141-145.

Khan TA, Mazid M, Ansari SA, Azam A, Naeem A. 2012. Zinc oxide nanoparticles promote the aggregation concanavalin A. 
Int. J. Pep. Res. Ther. 3: 23-27.

Koukoulakis P.H., Simonis A.D., Bladenopoulou S. 1988. Potassium-magnesium antagonism into tomato and cucumber, growing plastic greenhouse. Proceedings of Athens Academy 63: 130-139.

Kumar A., Biswas T.K., Singh N., Lal E.P. 2014. Effect of gibberellic acid on growth, quality and yield of tomato (Lycopersicon esculentum Mill.). J. Agricult. Vet. Sci. 7: 28-30.

Lichtenthaler H.K., Wellburn A.R. 1983. Determinations of total carotenoids and chlorophylls $a$ and $b$ of leaf extracts in different solvents. Biochem. Soc. Trans. 11: 591-592.

Lin D., Danfeng H. 2003. Effects of potassium levels on photosynthesis and fruit quality of muskmelon in culture medium. Acta Hortic. Sinica 30: 221-223.

Mazumdar F. 2013. Response of gibberellic acid and potash nutrient on growth and yield of late planting cabbage. M.Sc. Thesis, Sher-e-bangla Agricultural University, Bangladesh.

Nasiri Y., Zehtab-Salmasi S., Nasrullahzadeh S., Najafi N., Ghassemi-Golezani, K. 2010. Effects of foliar application of micronutrients (Fe and $\mathrm{Zn}$ ) on flower yield and essential oil of chamomile (Matricaria chamomilla L.). J. Med. Plants Res. 4: $1733-1737$.

Paroussi G., Voyiatzis D.G., Paroussi E., Drogour P.D. 2002. Growth, flowering and yield responses to $\mathrm{GA}_{3}$ of strawberry grown under different environmental conditions. Sci. Hortic. 96: 103-113.

Quddasi S., Khan F., Mazid M., Khan T.A, Shakeel A., Arshad M. 2014. Quality status of nutrients, vitamins and hormones under pathological threats in tomato: Basic scenario. Med. Chem. Anal. 4: 12-21.

Radford P.J. 1967. Growth analysis formulae - Their use and abuse. Crop Sci. 7: 171-175.

Roy R., Nasiruddin K.M. 2011. Effect of different level of GA on growth and yield of cabbage. J. Environ. Sci. Nat. Resour. 4: 79-82.

Sestak Z., Catsk J., Jarvis P.G. 1971. Plant Photosynthetic Production Manual of Methods. Junk W.N.V. Publication, Hague.

Shah S.H., Ahmad I, Samiullah. 2006. Effect of gibberellic acid spray on growth, nutrient uptake and yield attributes during various growth stages of Black cumin (Nigella sativa L.). Asian J. Plant Sci. 5: 881-884.

Sharma P., Sardana V., Sukhvinder Singh. 2013. Dry matter partitioning and source-sink relationship as influenced by foliar sprays in groundnut. The Bioscan 8: 1171-1176.

Song J.Q., Fujjiyama H. 1996. Amelorative effect of potassiumon rice and tomato subjected to sodium salinization. Soil Sci. Plant Nutr. 42: 493-501.

Talon M., Zarcarias L., Primo-Millo E. 1992. Gibberellins and parthenocarpic ability in developing ovaries of seedless mandarins. Plant Physiol. 99: 1575-1581.

Tiwari D.K., Pandey P., Giri S.P., Dwivedi J.L. 2011. Effect of $\mathrm{GA}_{3}$ and other plant growth regulators on hybrid rice seed production. Asian J. 10: 133-139.

Tuna A.L., Kaya C., Ashraf M. 2010. Potassium sulfate improves water deficit tolerance in melon plants grown under glasshouse conditions. J. Plant Nutr. 33: 1276-1286.

Vanbel A.J.E. 1990. Xylem-phloem exchange via the rays: the undervalued route of transport. J. Exp. Bot. 41: 631-644.

Wang Y.H., Thomas C.E., Dean R.A. 1997. A genetic map of melon (Cucumis melo L.) based on amplified fragment length polymorphism (AFLP) markers. Theor. Appl. Genet. 95: 791798. 